\title{
Penyuluhan Pengaturan Pola Makan dan Gizi Seimbang untuk Siswa Sekolah Sepak Bola di Cilacap Selatan
}

\author{
Elida Soviana*1 \\ 1Ilmu Gizi, Fakultas Ilmu Kesehatan, Universitas Muhammadiyah Surakarta, Indonesia \\ *e-mail: es121@ums.ac.id ${ }^{1}$
}

\begin{abstract}
Abstrak
Pola makan yang baik dan gizi seimbang dibutuhkan oleh setiap olahragawan dan atlet untuk menunjang performa pada saat latihan maupun pertandingan. Oleh sebab itu, setiap olahragawan dan atlet harus memiliki pengetahuan yang baik tentang pola makan dan gizi seimbang tersebut. Pengetahuan gizi yang kurang pada anak-anak dan orangtua menyebabkan asupan gizi inadekuat. Asupan gizi yang inadekuat pada atlet dapat menyebabkan performa atlet kurang baik, atlet Siswa Sekolah Sepak Bola (SSB) SPARTAN yang bertempat di Kabupaten Cilacap mengikuti latihan sepak bola 1 minggu selama 4 kali. Pada satu tahun terakhir terdapat 32\% siswa yang sakit dan kebugaran fisiknya kurang setelah melakukan latihan. Tujuan kegiatan pengabdian adalah meningkatkan pengetahuan kepada orangtua siswa tentang pola makan dan gizi seimbang. Penyuluhan dilakukan kepada 55 siswa beserta orangtua mereka. Penyuluhan diberikan dengan menggunakan media leafleat dan powerpoint. Sebelum dan setelah penyuluhan para peserta mendapatkan kuesioner. Berdasarkan hasil pengabdian diketahui bahwa terdapat peningkatan pengetahuan dari siswa dan orang tua siswa terhadap pola makan dan gizi seimbang.
\end{abstract}

Kata kunci: Gizi Seimbang, Leaflet, Penyuluhan, Pola Makan.

\begin{abstract}
A good diet and balanced nutrition are needed by every athlete and athlete to support performance during training and competition. Therefore, every sportsman and athlete must have a good knowledge of this balanced diet and nutrition. Inadequate nutritional knowledge in children and parents causes inadequate nutritional intake. Inadequate nutritional intake for athletes can lead to poor athlete performance, SPARTAN Football School (SSB) Student athletes who are located in Cilacap Regency participate in soccer practice 1 week for 4 times. In the last one year there were $32 \%$ of students who were sick and had poor physical fitness after doing the exercises. The purpose of this service activity is to increase the knowledge of parents of students about eating patterns and balanced nutrition. Outreach was carried out to 55 students and their parents. Extension was provided using leafleat and powerpoint media. Before and after counseling, the participants received a questionnaire. Based on the results of the service, it is known that there is an increase in the knowledge of students and parents of students about balanced diet and nutrition.
\end{abstract}

Keywords: Balanced Nutrition, Leaflets, Counseling, Diet.

\section{PENDAHULUAN}

Sekolah Sepak Bola (SSB) SPARTAN di Cilacap Selatan adalah sebuah sekolah yang mengajarkan mengenai teknik-teknik dalam sepak bola kepada siswa yang berumur diantara 917 tahun. Umur tersebut merupakan umur di kisaran anak-anak sampai remaja. Pada umur tersebut, siswa membutuhkan asupan gizi yang baik untuk mendukung pertumbuhan fisik dan performa pada saat latihan maupun pertandingan sepak bola[1. Atlet sepakbola perlu diberikan menu khusus pola makan dan pengaturan gizi yang menjadi panduan bagi para atletnya dengan tersedianya tim khusus pengelola makanan atlet sepakbola pada setiap pusat-pusat sekolah sepak bola[2].

Di Sekolah Sepak Bola SPARTAN dilakukan latihan 4 kali dalam seminggu, yaitu pada hari senin, rabu, jumat dan minggu. Latihan dilakukan pada jam 15.30 - 17.30 untuk hari senin, rabu, dan jumat. Sedangkan untuk hari minggu, latihan dilakukan pada jam 07.00 - 09.00. Pengaturan gizi yang baik pada saat latihan maupun pertandingan akan mengarahkan atlet untuk memiliki kondisi kebugaran yang baik dalam berkompetisi untuk mencapai prestasi[3]. Sekolah Sepak Bola 
SPARTAN sering mengikuti turnamen setiap tahunnya. Turnamen dibagi menjadi 4 kelompok, yaitu :

1. Kelompok anak usia $<10$ tahun.

2. Kelompok anak usia $<13$ tahun.

3. Kelompok anak usia $<15$ tahun.

4. Kelompok anak usia $<17$ tahun.

Berdasarkan survey pendahuluan pada tanggal 21 Mei 2016 di SSB SPARTAN para siswa maupun orang tua di Sekolah Sepak Bola SPARTAN jarang yang memperhatikan mengenai pola makan yang baik dan asupan gizi yang sesuai kebutuhan. Pada 1 tahun terakhir terdapat sebanyak $32 \%$ siswa yang sakit pada saat setelah melakukan latihan dan siswa yang tidak sarapan sebelum melakukan latihan.

Pengaturan pola makan yang baik adalah 3 kali makan utama dan 3 kali makan selingan. Selain itu, pengaturan pola makan harus berpedoman pada PUGS (Pedoman Umum Gizi Seimbang) yang meliputi :
a. Makanlah aneka ragam makanan
b. Makanlah makanan untuk memenuhi kecukupan energi
c. Makanlah sumber karbohidrat setengah dari kebutuhan energi
d. Batasi konsumsi lemak dan minyak sampai seperempat dari kebutuhan energi
e. Gunakan garam beryodium
f. Makanlah makanan sumber zat besi
g. Berikan ASI saja pada bayi sampai umur 6 bulan
h. Biasakan makan pagi
i. Minumlah air bersih, aman yang cukup jumlahnya
j. Lakukan aktivitas fisik dan olahraga secara teratur
k. Hindari minum minuman beralkohol
1. Makanlah makanan yang aman bagi kesehatan
m. Bacalah label pada makanan yang dikemas

Pola makan yang baik dan gizi seimbang dibutuhkan oleh setiap olahragawan dan atlet untuk menunjang performa pada latihan maupun pada saat pertandingan[4]. Oleh sebab itu, setiap olahragawan dan atlet harus memiliki pengetahuan yang baik tentang pola makan dan gizi seimbang tersebut. Pengetahuan yang baik akan dapat mempengaruhi sikap dan perilaku tentang pola makan dan pemilihan bahan makanan, sehingga dapat mendukung performa dan kebugaran atlet sepak bola. Pengetahuan gizi khususnya untuk atlet mempunyai peranan penting dalam pemilihan makanan dan minuman yang tepat. Hal tersebut bertujuan untuk menunjang peningkatan kesehatan fisik dan diharapkan pada waktunya atlet dapat menunjang prestasinya yang terbaik[5].

Sekolah Sepak Bola (SSB) SPARTAN pada saat ini hanya mengajarkan mengenai teknik dalam bermain sepakbola tanpa memberikan pengajaran dan pengetahuan mengenai gizi kepada para siswanya. Sampai saat ini, di SSB tersebut belum pernah memberikan edukasi tentang gizi, baik kepada siswa maupun kepada orang tua siswa. Di SSB tersebut, ditemukan permasalahan, baik pada saat latihan maupun setelah latihan berlangsung, yaitu banyak siswa yang mengalami sakit dikarenakan oleh :

1. Sebanyak $32 \%$ siswa yang sakit setelah melakukan latihan

2. Beberapa siswa tidak sarapan pagi.

3. Beberapa siswa tidak memperoleh asupan gizi yang baik pada saat latihan atau pada saat pertandingan.

4. Beberapa siswa tidak bugar saat melakukan latihan.

Hal ini memperlihatkan bahwa di SSB tersebut, pola makan dan gizi tidak mendapatkan perhatian yang baik oleh siswa maupun orang tua. Oleh sebab itu, dibutuhkan sebuah media untuk memberikan pengetahuan mengenai gizi kepada orang tua di SSB SPARTAN tersebut. 
Solusi yang ditawarkan untuk permasalahan mitra di atas adalah dengan mengadakan penyuluhan kepada orang tua dari siswa sekolah sepak bola SPARTAN. Penyuluhan dilakukan dengan media leafleat dan powerpoint dengan menggunakan metode ceramah dan tanya jawab. Dengan adanya penyuluhan tersebut, maka siswa beserta orang tua akan memiliki pengetahuan mengenai pola makan dan gizi seimbang yang baik pada waktu latihan maupun waktu turnamen sepak bola berlangsung.

\section{PELAKSANAAN KEGIATAN}

Kegiatan penyuluhan dilaksanakan pada Hari Minggu, tanggal 24 Juli 2016 jam 09.00 12.00 WIB. Terdapat 55 perserta penyuluhan yang terdiri dari siswa beserta orang tua dari Sekolah Sepakbola (SSB) SPARTAN di Cilacap Selatan. Tempat pelaksanaan penyuluhan dilakukan di Pendapa Kecamatan Cilacap Selatan. Waktu untuk kegiatan penyuluhan ini 3 jam dengan alokasi disajikan seperti dalam Tabel 1 berikut.

Tabel 1. Alokasi Waktu Untuk Kegiatan Pelatihan

\begin{tabular}{lc}
\hline \multicolumn{1}{c}{ Kegiatan } & Alokasi Waktu \\
\hline Pembukaan dan Pengisian Kuesioner Awal & 15 menit \\
Pembagian Leafleat & 10 menit \\
Sesi materi : Penyuluhan Pola Makan dan Gizi Seimbang & 100 menit \\
Sesi Tanya Jawab & 40 menit \\
Pengisian Kuesioner Akhir \& Penutup & 15 menit \\
\hline
\end{tabular}

Alat dan bahan yang digunakan dalam pengabdian ini diantaranya adalah sebagai berikut:

1. LCD proyektor untuk menyampaikan materi pelatihan.

2. Laptop untuk media penyampaian materi.

3. Leaflet pelatihan berupa hard copy dan softcopy.

4. Perangkat-perangkat pendukung (biodata peserta, daftar hadir peserta, lembar kuisioner)

Kegiatan penyuluhan dapat ditunjukkan oleh gambar 1, sedangkan peserta penyuluhan dapat ditunjukkan oleh gambar 2 .

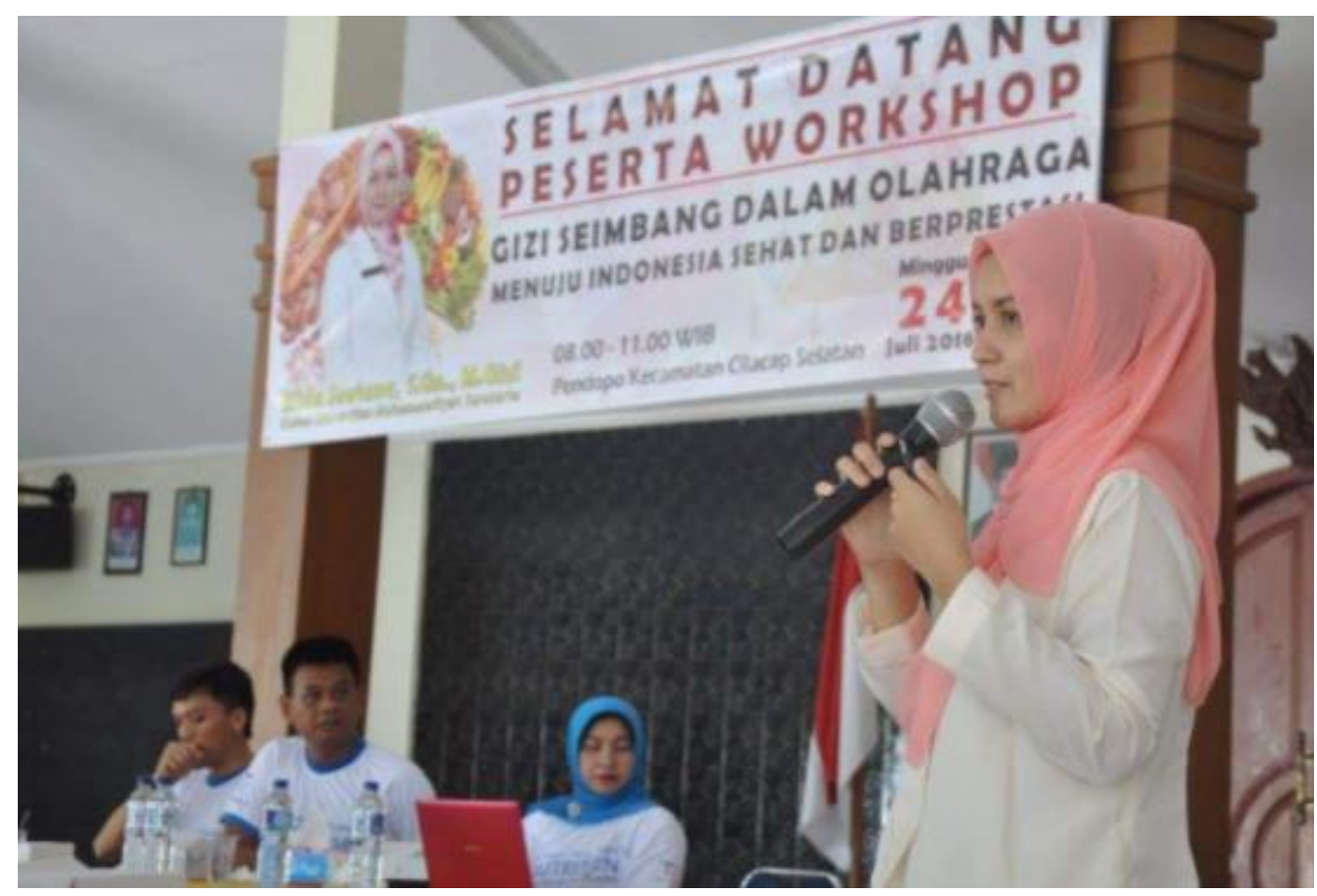

Gambar 1. Sesi Penyuluhan 


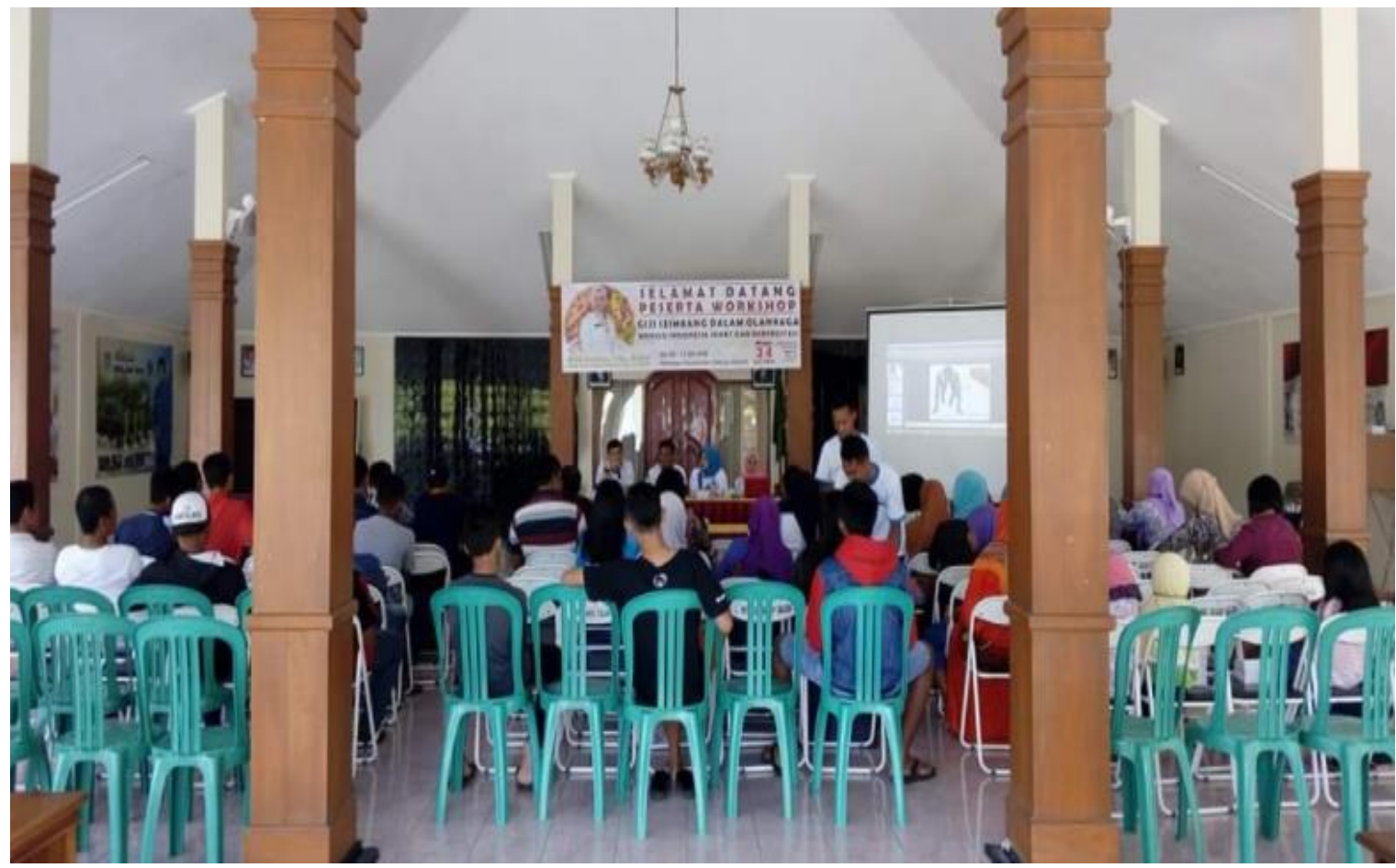

Gambar 2. Peserta Penyuluhan

Hasil dari penyuluhan diukur dengan menggunakan form kuesioner yang berisi pertanyaan-pertanyaan terkait dengan pengetahuan peserta tentang pola makan dan gizi seimbang. Kuesioner dilakukan dua kali, secara langsung yaitu sebelum penyuluhan dan setelah penyuluhan. Hal ini dilakukan dengan tujuan supaya dapat diketahui pengetahuan awal sebelum dan setelah diberikan penyuluhan. Hasil skor pre test dan post test dapat dilihat pada Tabel 2.

Tabel 2. Hasil Skor Pre test dan Post test

\begin{tabular}{lccc}
\hline \multicolumn{1}{c}{ Aspek } & Pre-Test & Post-Test & $\boldsymbol{p}_{\text {-value }} \boldsymbol{y}^{*}$ \\
\hline Mean & 62.0 & 86.3 & 0.001 \\
Minimum & 52 & 92 & \\
Maksimun & 72 & 100 & \\
\hline
\end{tabular}

*paired t-test

Berdasarkan Tabel 2 menunjukkan rata-rata skor peserta sebelum penyuluhan adalah 62 dengan nilai terendah 52 dan tertinggi 72 . Setelah diberi penyuluhan rata-rata skor meningkat menjadi 86.3 dengan nilai terendah 92 dan tertinggi 100. Berdasarkan hasil pengabdian diketahui bahwa nilai p 0.001 yang berarti bahwa terdapat perbedaan pengetahuan peserta sebelum dan setelah penyuluhan.

Pengetahuan merupakan suatu domain dari hal yang dapat membentuk perilaku seseorang. Dengan adanya pelatihan maupun penyuluhan, pengetahuan peserta dapat ditingkatkan[6]-[8]. Hal ini sejalan dengan kegiatan yang telah dilakukan, yaitu pengetahuan peserta dapat meningkat setelah mendapatkan penyuluhan tentang pola makan dan gizi seimbang.

Hasil pengabdian menunjukkan bahwa peserta penyuluhan mengalami peningkatan nilai pengetahuannya setelah kegiatan penyuluhan. Berdasarkan hasil pengabdian untuk keseluruhan peserta memiliki peningkatan rata-rata skor pre test sebesar 24.3 dari 62.0 menjadi 86.3. Nilai terendah juga mengalami peningkatan sebesar 40 point, dari 52 menjadi 92, sedangkan nilai tertinggi mengalami peningkatan sebesar 28 point, dari 72 menjadi 100.

Pada awalnya, peserta kurang mengetahui tentang pola makan dan gizi seimbang. Walaupun awalnya memiliki pemahaman yang minim, kegiatan penyuluhan terbukti dapat 
meningkatkan pemahaman peserta. Beberapa kegiatan telah membuktikan bahwa walaupun pemahaman peserta minim mengenai suatu hal, apabila pelatihan, penyuluhan, maupun pemberian informasi dilakukan dengan baik dan benar, maka pengetahuan peserta kegiatan akan meningkat[9]-[12].

Penyuluhan dapat menjadi stimulus untuk dapat merubah terjadinya perubahan perilaku dengan meningkatkan kekuatan-kekuatan pendorong dalam proses perubahan perilaku. Hasil dari kuesioner akhir menunjukkan bahwa penyuluhan yang telah dilakukan di SSB SPARTAN Cilacap Selatan berhasil meningkatkan pengetahuan peserta, baik siswa maupun orang tua dari siswa SSB tersebut.

\section{KESIMPULAN}

Kesimpulan yang dapat diambil dari pengabdian masyarakat ini adalah bahwa para peserta mendapatkan pengetahuan mengenai pola makan yang baik untuk atlet sepakbola serta para peserta mendapatkan pengetahuan mengenai gizi seimbang untuk atlet sepakbola.

\section{UCAPAN TERIMA KASIH}

Penulis mengucapkan terima kasih kepada Universitas Muhammadiyah Surakarta sebagai penyandang dana kegiatan ini serta Sekolah Sepak Bola Spartan Cilacap.

\section{DAFTAR PUSTAKA}

[1] M. H. Williams, "Nutrition For Health, Fitness and Sport-7th Edition", New York : McGrawHill, 2005.

[2] FIFA, "Nutrition For Football: A Practical Guide To Eating and Drinking for Health and Performance[internet]", Zurich : F-Marc, 2016.

[3] D.P. Irianto, "Panduan Gizi Lengkap Keluarga dan Olahragawan", Yogyakarta : Andi Offset, 2007.

[4] E.S. Bagustila, Sulistiyani, I. Nafikadini,"Konsumsi Makanan, Status Gizi dan Tingkat Kebugaran Atlet Sepakbola Jember United FC". Artikel Ilmiah Hasil Penelitian Mahasiswa 2015.

[5] F. Maghfirah, A. Wijanarka, N. I. Arovah, "Hubungan Tingkat Pengetahuan Gizi Olahraga, Frekuensi Konsumsi Suplemen dan Status Gizi dengan Kebugaran Jasmani Atlet di Klub Sepakbola PSIM Yogyakarta", Journal Medika Respati, Vol 8, No 1, 2013.

[6] Y. I. Kurniawan, "Pelatihan Aplikasi Pengukuran Minat Kejuruan Siswa Bagi Guru Sekolah Menengah Kejuruan (SMK) Se-Jawa Tengah,” War. LPM, vol. 19, no. 2, pp. 149-155, 2017, doi: 10.23917/warta.v19i2.2224.

[7] U. Rahmi, A. Hidayati, and Azrul, "Pelatihan E-Learning untuk Mengintegrasikan TIK dalam Pembelajaran bagi Guru-guru SMA,” J. Panrita Abdi, vol. 4, no. 1, pp. 34-41, 2020, [Online]. Available: http://journal.unhas.ac.id/index.php/panritaabdi.

[8] D. R. Novian, "Optimalisasi Penggunaan Google Classroom Sebagai Media E-Learning Bagi Mahasiswa Kedokteran Hewan Universitas Nusa Cendana," J. Pengabdi. Kpd. Masy. MEMBANGUN NEGERI, vol. 3, no. 2, pp. 7-12, 2019, doi: 10.35326/pkm.v4i2.414.

[9] Y. I. Kurniawan, "PEMBANGUNAN WEBSITE INFORMASI SEKOLAH DI SMA NEGERI KERJO , KARANGANYAR,” J. Pengabdi. Kpd. Masy., vol. 2, no. 1, pp. 71-84, 2018.

[10] Y. I. Kurniawan, N. Chasanah, and Nofiyati, "Pengembangan Website Informasi Sekolah di SMP Negeri 2 Kalimanah, Purbalingga," J. Solma, vol. 09, no. 02, pp. 335-346, 2020, doi: http://dx.doi.org/10.22236/solma.v9i2.5440. 
[11] K. N. P. Pamungkas, J. Riadi, I. Hastuti, and Y. Indrasary, "Pengembangan Dan Pelatihan Penggunaan E-Learning Pada Mts Muhammadiyah 3 Al-Furqon Banjarmasin," J. IMPACT Implement. Action, vol. 1, no. 1, pp. 11-17, 2018, doi: 10.31961/impact.v1i1.633.

[12] H. B. Santoso, R. Delima, and A. Wibowo, "Pelatihan Pengembangan Web Profil Desa bagi Aparatur Pemerintah Desa," E-DIMAS J. Pengabdi. Kpd. Masy., vol. 10, no. 1, pp. 41-48, 2019. 